\title{
Reputasi Kantor Akuntan Publik, Prediksi Kebangkrutan, Profitabilitas dan Audit Delay
}

\author{
Ni Luh Komang Winda Sindu Maharani ${ }^{1}$ \\ Fakultas Ekonomi dan Bisnis \\ Universitas Udayana, Indonesia
}

\author{
I Ketut Sujana ${ }^{2}$ \\ Fakultas Ekonomi dan Bisnis \\ Universitas Udayana, Indonesia
}

\section{Surel : windasindu15@gmail.com}

\section{ABSTRAK}

Proses audit yang panjang akan memengaruhi ketepatan waktu dalam publikasi laporan keuangan kepada publik. Keterlambatan publikasi akan mengurangi manfaat dari laporan keuangan perusahaan, sehingga diperlukannya pengetahuan mengenai faktor-faktor yang memengaruhi audit delay. Adapun tujuan dari penelitian ini guna mengetahui korelasi reputasi kantor akuntan publik, prediksi kebangkrutan, dan profitabilitas pada audit delay. Penelitian ini dilaksanakan di entitas sektor pertambangan yang melantai di Bursa Efek Indonesia kurun waktu 2017-2019. Sampel penelitian diseleksi dengan metode purposive sampling sebesar 40 perusahaan yang diteliti selama 3 tahun periode dengan menggunakan laporan keuangan tahunan. Metode pengumpulan data dan teknik analisis data yang digunakan adalah metode observasi non partisipan dan analisis regresi linear berganda. Hasil penelitian ini menunjukan bahwa reputasi kantor akuntan publik mempunyai pengaruh negatif pada audit delay, prediksi kebangkrutan mempunyai pengaruh negatif pada audit delay, dan profitabilitas mempunyai pengaruh negatif pada audit delay.

Kata Kunci: Reputasi Kantor Akuntan Publik; Prediksi Kebangkrutan; Profitabilitas; Audit Delay.

\section{Public Accounting Firm Reputation, Bankruptcy Prediction, Profitability and Audit Delay}

\section{ABSTRACT}

The lengthy audit process will affect the timeliness in the publication of financial statements to the public. The delay in publication will reduce the benefits of the company's financial statements, so knowledge is needed about the factors that affect audit delay. The purpose of this study was to determine the effect of public accounting firm reputation, bankruptcy prediction, and profitability on audit delay. This research was conducted in mining sector companies listed on the Indonesia Stock Exchange for the 2017-2019 period. The research sample was selected using a purposive sampling method as many as 40 companies were studied over a 3 years period using annual financial statements. Data collection methods and data analysis techniques used are non-participant observation methods and multiple linear regression analysis. The results of this study indicate that the reputation of a public accounting firm has a negative effect on audit delay, bankruptcy prediction has a negative effect on audit delay, and profitability has a negative effect on audit delay.

Keywords: Public Accounting Offices; Bankruptcy Prediction; Profitability; Audit Delay.

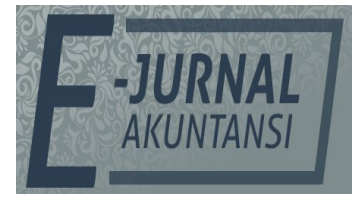

e-ISSN 2302-8556

Vol. 31 No. 8

Denpasar, Agustus 2021

Hal. 2116-2127

DOI:

10.24843/EJA.2021.v31.i08.p18

PENGUTIPAN:

Maharani, N.L.W.S., \& Sujana, I K. (2021). Reputasi Kantor Akuntan Publik, Prediksi Kebangkrutan, Profitabilitas dan Audit Delay. E-Jurnal Akuntansi, 31(8), 2116-2127

RIWAYAT ARTIKEL: Artikel Masuk: 28 Juli 2021 Artikel Diterima: 25 Agustus 2021

Artikel dapat diakses : https://ojs.unud.ac.id/index.php/Akuntansi/index 


\section{PENDAHULUAN}

Pada masa globalisasi, dunia bisnis mulai mengalami kemajuan seiring munculnya usaha/bisnis baru pada setiap tahun. Hal-hal yang turut menyokong kemajuan di dunia bisnis ialah kemajuan teknologi, teknologi dapat mempermudah para pebisnis dalam memajukan bisnisnya, khususnya dalam hal investasi di pada Bursa Efek Indonesia (Arifuddin et al., 2017). Investasi memerlukan data-data serta informasi yang akurat serta tepat waktu sebagai bahan pada proses pengambilan keputusan (Panggabean \& Yendrawati, 2016). Entitas yang menjual sahamnya melalui bursa efek bertanggung jawab untuk menyajikan laporan keuangan yang sudah memenuhi syarat standar keuangan (Soyemi et al., 2019). Hal-hal yang tersaji pada laporan keuangan dikatakan memberi manfaat jika tersajikan dengan akurat serta tepat ketika diperlukan bagi para pengguna laporan keuangan (Warrad, 2018).

Auditor merupakan sebagai pihak ketiga yang independen terhadap perusahaan dan akan menilai keakuratan laporan keuangan. Pihak ketiga yang kompeten serta bersifat independen berperan dalam pemeriksaan laporan keuangan (Saragih, 2019). Audit delay merupakan durasi yang dibutuhkan pihak auditor untuk menuntaskan aktivitas audit dimulai pada tanggal tutup tahun buku sampai tanggal diselesaikannya laporan audit. Audit delay dapat memunculkan akibat pada ketepatan waktu publikasi laporan keuangan, serta laporan keuangan yang disebar-luaskan mampu berdampak pada perusahaan (Salleh et al., 2017)

Setiap tahunnya, selalu ada beberapa entitas yang telat menyampaikan laporan keuangannya (Sari et al., 2019). Menurut pengumuman Bursa Efek Indonesia, terdapat 64 perusahaan yang belum menyampaikan laporan keuangan auditan Per 31 Desember 2019 yang tercatat hingga 2 Juni 2020 dan diantaranya terdapat lima perusahaan tambang. Kemudian, terdapat 64 perusahaan yang belum menyampaikan laporan keuangan auditan yang berakhir per 31 Desember 2018 yang tercatat hingga 1 April 2019 dan diantaranya delapan perusahaan tambang. Pada lampiran pengumuman BEI mengenai Penyampaian Laporan Keuangan Auditan yang berakhir per 31 Desember 2017 dan 2018, perusahaan tambang mendominasi dalam perusahaan-perusahaan yang tercatat dan sebagian besar perusahaan yang disuspensi oleh BEI merupakan perusahaan pertambangan. Hingga dipublikasikannya pengumuman terakhir tersebut, terdapat sepuluh perusahaan tercatat yang belum menyampaikan laporan keuangan tahunan auditan per tanggal 31 Desember 2018 hingga 29 Juni 2019 dan tiga diantaranya perusahaan sektor pertambangan, serta dari sepuluh perusahaan tercatat pada lampiran pengumuman BEI mengenai Penyampaian Laporan Keuangan Auditan yang Berakhir per 31 Desember 2017, terdapat enam perusahaan yang belum menyampaikan laporan keuangan auditan 2017 dan tiga diantaranya merupakan perusahaan tambang. Hal ini mengindikasikan bahwa perusahaan dari sektor pertambangan masih banyak yang belum mempublikasi laporan keuangan auditan dan sebagian perusahaannya terlambat dalam melaporkan laporan.

Kecepatan pada proses audit ditetapkan berdasarkan kualitas sebuah kantor akuntan publik tersebut. Hal ini kaitannya dengan faktor luar sebuah entitas yakni kualitas Kantor Akuntan Publik (KAP). KAP big four akan memberi kualitas 
kinerja yang efektif serta efisien, jadi audit mampu di selesaikan tepat pada waktu yang ditentukan. Penyebabnya adalah KAP big four mempunyai keahlian, pengetahuan, sumber daya dan juga staf yang lebih professional, hal ini tentu mempersingkat waktu dalam proses pengauditan serta meminimalisir terjadinya audit delay (Aslam et al., 2017). Prediksi kebangkrutan dapat mempengaruhi audit delay karena semakin perusahaan diprediksi akan mengalami kebangkrutan, maka perusahaan mengalami kesulitan finansial. Hal ini menyebabkan perusahaan membutuhkan rentang waktu audit delay yang semakin panjang karena auditor memerlukan waktu yang semakin lama dalam hal melakukan pemeriksaan pada entitas terebut. Tingginya nilai profitabilitas merepresentasikan kualitas pekerjaan manajemen yang dapat dikatakan baik. Hal ini berpengaruh pada cepatlambatnya manajemen untuk melaporkan pekerjaannya.

Penelitian ini menggunakan teori kepatuhan, yang mana terdiri dari dua aspek secara umum pada Pustaka sosiologi tentang kepatuhan terhadap hukum, yaitu instrumental serta normative (Tyler, 1989). Aspek ekonomi perspektif lebih menggunakan perspektif normatif yang kaitannya dengan hal-hal yang dianggap sebagai moral bagi Sebagian orang tetapi bertolak belakang dengan kebutuhan pribadinya. Organisasi maupun individu lebih patuh terhadap hukum yang dianggap selaras serta bersifat konsisten dengan norma yang berlaku dan hal ini juga dilakukan karena adanya tuntutan berupa aturan-aturan. Tuntutan atau ketaatan terhadap waktu penyampaian laporan keuangan sebuah entitas publik diatur pada Peraturan Otoritas Jasa Keuangan. Hal ini mengindikasikan bahwa tolak ukur kinerja audior dan perusahaan dalam penyelesaian laporan keuangan dilihat dari kepatuhan mereka menyelesaikan penugasan audit dan publikasi laporan keuangan secara tepat waktu (Pratiwi \& Wiratmaja, 2018).

Teori agensi adalah versi game theory yang mengkotakkan proses kontrak antar dua pihak ataupun lebih, serta setiap pihak yang terkait pada kontrak berusaha memperoleh yang terbaik untuk dirinya (Scott, 2012). Teori agensi menjelaskan prinsipal tiada lain adalah orang yang memberi pekerjaan pada agen untuk menjalankan pekerjaan sesuai harapan prinsipal dan agen adalah pihak manajemen yang mengetahui lebih banyak informasi mengenai perusahaan (Abdillah et al., 2019). Pemeriksaan bertujuan untuk meyakinkan bahwa pihak manajer sebagai agen yang menjalankan tugasnya berdasarkan keinginan pihak prinsipal, yaitu auditor eksternal sebagai pihak independen perusahaan (Aprila et al., 2017). Waktu penyampaian laporan keuangan yang tepat waktu diharapkan dapat meminimalisir risiko perbedaan informasi yang timbul antara sebuah entitas dengan publik. Laporan keuangan yang disampaikan dengan tepat pada waktunya mampu meminimalisir kemungkinan penyelewengan pihak agen yang tiada lain adalah yang mempunyai data lebih banyak jika diperbandingkan dengan pihak prinsipal guna menyalahgunakan informasi manajemen demi kepentingannya sendiri (Praptika \& Rasmini, 2016).

Teori sinyal yang menjelaskan bahwa melibatkan dua pihak, yakni oleh perusahaan yaitu sebagai pihak manajemen kepada pihak luar (Spence, 1973). Teori sinyal lebih menekankan pada pentingnya informasi yang dikeluarkan perusahaan terhadap keputusan investasi pihak di luar entitas. Sesungguhnya, pihak eksternal seperti investor ataupun kreditor akan menanggapi hal itu sebagai sinyal berita baik atau berita buruk (Sari \& Priyadi, 2016). Hubungan teori sinyal 
dengan penelitian ini bahwa nilai profitabilitas dianggap sebagai sinyal bagi publik dalam menilai baik buruknya suatu perusahaan karena semakin profitabilitas tinggi semakin baik pula peluang investasi di perusahaan tersebut. Kemudian, keadaan perusahaan yang diprediksi tidak bangkrut atau keuangannya dalam keadaan baik merupakan sinyal baik bagi kreditor dan investor karena perusahaan seperti itu baik dalam mengelola operasi dan keuangan perusahaannya sehingga publik percaya dalam menaruh modalnya di perusahaan tersebut. Reputasi KAP yang baik juga menunjukan sinyal yang bagus karena reputasi yang baik mempengaruhi ketepatan penyelesaian laporan keuangan auditan dan semakin baik reputasi KAP akan meningkatkan kepercayaan publik bahwa laporan keuangan. Apabila audit delay semakin panjang, dapat mengakibatkan mobilitas saham semakin tidak pasti. Alhasil, investor beranggapan bahwa panjangnya audit delay diakibatkan oleh adanya sinyal buruk. Berikut kerangka konseptual sesuai dari paparan pendahuluan.

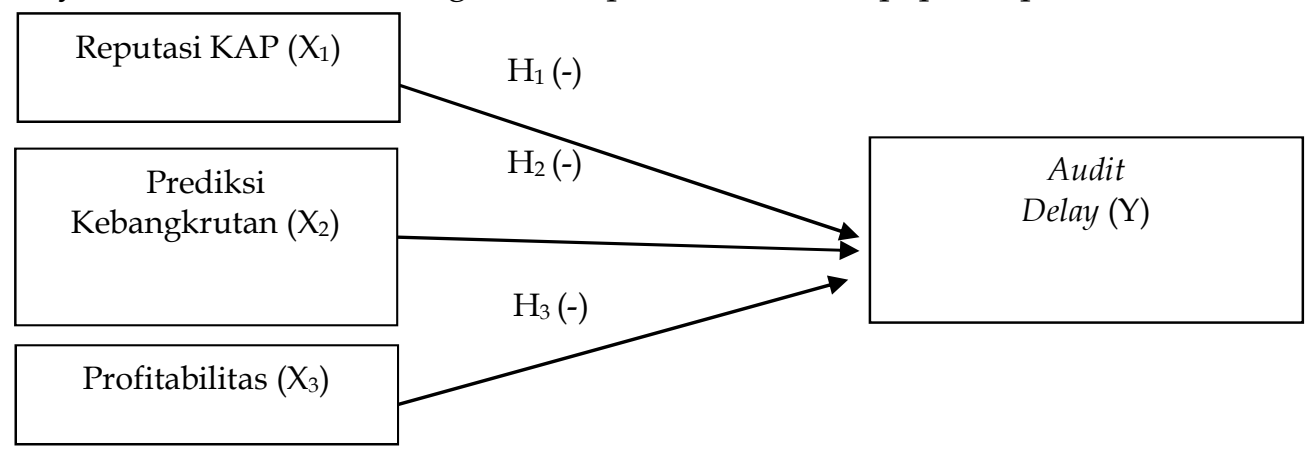

Sumber: Data Penelitian, 2021

\section{Gambar 1. Kerangka Konseptual Penelitian}

Kantor Akuntan Publik (KAP) didefinisikan sebagai perusahaan yang berdiri atas dasar ketentuan perundang-undangan yang telah memperoleh izin praktik sesuai Undang-Undang tentang Akuntan Publik. Laporan keuangan yang nantinya disampaikan oleh sebuah entitas, harus diaudit terlebih dahulu oleh pihak KAP (Suparsada \& Putri, 2017). Hal ini karena entitas yang listing di BEI berkewajiban untuk menyajikan laporan keuangan yang sudah diaudit. Entitas membutuhkan jasa dari seorang auditor independen yang berkualitas serta bereputasi baik, jadi dapat membantu menyampaikan laporan keuangan dengan rutin serta tepat pada waktu yang ditentukan. Kualitas audit KAP terbagi atas dua golongan, yakni KAP big four serta KAP non big four. KAP big four biasanya menuntaskan tugas audit dengan lebih cepat, sehingga menggunakan jasa KAP the big four diharapkan dapat menurunkan adanya ketidakselarasan informasi yang timbul diantara sebuah entitas dengan pihak pengguna laporan keuangan karena KAP the big four dianggap memiliki potensi kinerja yang lebih baik sehingga hasil audit lebih transparan dan memungkinkan dipublikasi secara tepat waktu. Hasil penelitian Verawati \& Wirakusuma (2016) berpengaruh negatif pada audit delay. Kemudian, pada penelitian Ocak \& Ozden (2018) reputasi KAP berpengaruh terhadap audit delay. Atas dasar pemaparan di atas, dapat ditarik hipotesis seperti berikut.

$\mathrm{H}_{1}$ : Reputasi kantor akuntan publik mempunyai pengaruh negatif pada audit delay. 
Keadaan sebuah entitas merupakan satu dari sekian penghambat proses audit, seperti misalnya saat auditor melakukan prediksi kebangkrutan sebuah usaha. Auditor memerlukan waktu yang lebih panjang guna menangani proses audit jika sebuah usaha diprediksikan akan bangkrut. Ini karena usaha yang diprediksikan akan bangkrut, biasanya menunda kegiatan pelaporan keuangannya, sebab auditor perlu waktu lebih lama untuk melakukan audit pada sebuah entitas serta membutuhkan informasi tambahan guna mengeluarkan pendapat (opini) yang tepat selaras dengan keadaan perusahaan itu sendiri. Penelitian yang dilakukan Santosa \& Dwirandra, (2016), memperoleh hasil bahwa prediksi kebangkrutan berpengaruh terhadap audit delay. Oleh karena itu semakin besar skor prediksi kebangkrutan suatu perusahaan akan mengakibatkan auditor lebih lama melakukan proses mengaudit sebab auditor perlu lebih banyak waktu guna menganalisa permasalahan yang ada. Oleh karena itu ditarik hipotesis sebagai berikut.

$\mathrm{H}_{2}$ : Prediksi kebangkrutan mempunyai pengaruh negatif pada audit delay.

Profitabilitas adalah suatu kemampuan perusahaan dalam mendapatkan laba melalui semua sumber yang ada, seperti penjualan, kas, aset, dan modal (Harahap, 2008). Rasio profitabilitas merupakan rasio yang tujuannya untuk memberi penilaian terhadap kekuatan sebuah entitas untuk menghasilkan laba, yang memberi ukuran tingkat efektivitas manajemen sebuah entitas (Kasmir, 2014). Entitas yang mengalami rugi ataupun tingkat profitabilitas yang rendah, mampu memberikan akibat buruk pada respon masyarakat serta mengakibatkan penurunan penilaian performa sebuah entitas (Yohaniar \& Asyik, 2017). Entitas yang mengalami laba, biasanya lebih tepat waktu untuk menyampaikan laporan keuangannya, alhasil mampu dengan cepat disampaikan ke investor serta para pihak pengguna laporan keuangan yang lain (Hapsari et al., 2016). Kekuatan sebuah entitas untuk menghasilkan laba ada hubungannya dengan audit delay. Profitabilitas diukur menggunakan ROA. Penelitian terdahulu oleh (Suparsada \& Putri (2017) dan Akingunola et al. (2018) menemukan, profitabilitas mempunyai pengaruh pada audit delay. Kemudian pada penelitian Prabasari \& Merkusiwati (2017) memperoleh hasil, profitabilitas mempunyai pengaruh negatif pada audit delay. Hal ini terjadi karena perusahaan yang mengumumkan profitabilitas yang relatif rendah memicu kemunduran pada publikasi laporan keuangan begitu juga sebaliknya.

$\mathrm{H}_{3}$ : Profitabilitas mempunyai pengaruh negatif pada audit delay.

\section{METODE PENELITIAN}

Penelitian berlokasi di adalah pada Bursa Efek Indonesia (BEI) dengan cara membuka website BEI, yakni www.idx.co.id. Penelitian dilakukan pada entitas sektor pertambangan yang telah listing di Bursa Efek Indonesia (BEI) pada periode 2017-2019. Hal ini karena bidang pertambangan adalah yang paling sesuai, dimana setiap tahunnya termasuk salah satu bidang yang mempunyai peran pada pertumbuhan perekonomian Indonesia (Pratiwi \& Wiratmaja, 2018). Obyek penelitian ini yakni reputasi KAP, prediksi kebangkrutan, profitabilitas, serta audit delay.

Audit delay merupakan jangka waktu penyelesaian pelaksanaan proses audit laporan keuangan tahunan suatu perusahaan yang diukur atas dasar 
rentang waktu tanggal tutup buku yakni 31 Desember sampai tanggal laporan auditor independen yang telah tercatat di laporan keuangan yang dibuat oleh auditor (Lestari \& Nuryatno, 2018). Pengukuran dilakukan secara kuantitatif dalam jumlah harian dengan mengurangkan tanggal laporan audit dengan tanggal laporan keuangannya (Kaaroud et al., 2020).

Audit Delay $=$ Tanggal laporan audit - Tanggal laporan keuangan

Nama baik KAP adalah bentuk kepercayaan masyarakat serta prestasi yang dimiliki auditor atas nama besar auditor itu sendiri (Verawati \& Wirakusuma, 2016). Reputasi KAP dapat digambarkan dengan korelasi afiliasi KAP dengan KAP yang tergolong KAP "big four" (Lestari et al., 2017). Reputasi auditor dapat diukur dengan variabel dummy. Entitas pemakai jasa KAP berafiliasi "big four" diberikan kode satu, entitas pemakai jasa KAP "non-big four" diberikan kode nol.

Skor prediksi kebangkrutan lebih besar pada perusahaan cenderung audit delay nya lebih panjang. Ini akibat entitas bisa jadi sedang dalam kondisi kesulitan dari segi keuangan yang dapat menunda pelaporan keuangan. Maka dari itu, auditor akan membutuhkan waktu lebih panjang dalam kegiatan audit, dan juga perlu informasi lainnya guna memberi opini agar selaras dengan keadaan entitas tersebut. Sesuai dengan penelitian Jayanti \& Rustiana (2015), model Grover adalah model prediksi yang mempunyai tingkat ketepatan tertinggi, sebesar 81,71\%. Kemudian hasil penelitian Heryanto (2020) dinyatakan bahwa model grover akurat dalam meramalkan prediksi perusahaan dimasa depan. Model grover tiada lain merupakan gambaran yang dibuat dengan melaksanakan pendesainan serta evaluasi atas model Altman Z-score. Jeffrey S. Grover memakai sampel seperti sampel pada model Altman Z-score. Atas pendesainan serta evaluasi ulang tersebut, Jeffrey S. Grover mendapatkan fungsi seperti berikut.

Skor $=1,650 \mathrm{X}_{1}+3,404 \mathrm{X}_{2}-0,016 \mathrm{ROA}+0,057$.

Keterangan:

$\mathrm{X}_{1} \quad=$ Working Capital/Total Asset

$\mathrm{X}_{2} \quad=$ Earnings before interest and taxes/Total Asset

$\mathrm{ROA}=$ Net Income/Total Asset

Profitabilitas ialah penilaian kekuatan suatu perusahaan guna menghasilkan laba (Riyanto, 2012). Pengukuran profitabilitas pada penelitian ini dilaksanakan dengan rasio Return on Asset (ROA) dengan rumus berikut ini (Kasmir, 2014).

ROA $=\frac{\text { Net Income }}{\text { Total Asset }} \times 100 \%$

Keterangan:

ROA = Rasio Tingkat Profitabilitas (Return on Assets)

Net Income $\quad=$ Total laba bersih perusahan setelah pajak

Total Asset = Total kekayaan yang dimiliki perusahaan

Metode pengumpulan data yang digunakan dalam penelitian ini yaitu metode observasi non partisipan. Populasi dalam penelitian ini yakni semua entitas pertambangan yang terdaftar dalam Bursa Efek Indonesia kurun waktu 2017-2019 sebanyak 50 persusahaan. Sampel diseleksi dengan teknik purposive sampling adalah suatu teknik pemilihan sampel dimana informasinya didapatkan dengan menyeleksi sesuai syarat-syarat tertentu (Sugiyono, 2017). Hasil seleksi pemilihan sampel adalah sebagai berikut. 
Tabel 1. Proses Seleksi Sampel Berdasarkan Kriteria

\begin{tabular}{|c|c|c|}
\hline No & Keterangan & $\begin{array}{c}\text { Total } \\
\text { Perusahaan }\end{array}$ \\
\hline 1 & $\begin{array}{l}\text { Entitas di bidang pertambangan yang melantai di BEI pada } \\
\text { periode } 2017-2019\end{array}$ & 51 \\
\hline 2 & $\begin{array}{l}\text { Entitas di bidang pertambangan yang tidak terdaftar berturut- } \\
\text { turut selama periode 2017-2019 }\end{array}$ & -6 \\
\hline 3 & $\begin{array}{l}\text { Entitas di bidang pertambangan yang tidak mempunyai tahun } \\
\text { tutup buku yang berakhir } 31 \text { Desember }\end{array}$ & 0 \\
\hline 4 & $\begin{array}{l}\text { Entitas di bidang pertambangan yang tidak menggunakan } \\
\text { mata uang Rupiah dalam laporan keuangannya }\end{array}$ & 0 \\
\hline 5 & $\begin{array}{l}\text { Entitas di bidang pertambangan yang delisting selama periode } \\
\text { 2017-2019 }\end{array}$ & -2 \\
\hline \multirow[t]{2}{*}{6} & $\begin{array}{l}\text { Entitas di bidang pertambangan yang tidak mempunyai data } \\
\text { yang lengkap yang berkaitan dengan variabel yang dipakai } \\
\text { atau entitas yang belum menyampaikan laporan keuangan } \\
\text { auditan } 2019 \text { hingga } 31 \text { Agustus } 2020\end{array}$ & -2 \\
\hline & Jumah Sampel & 41 \\
\hline \multirow[t]{3}{*}{7} & Jumlah sampel outlier & -1 \\
\hline & Jumlah sampel yang layak dalam penelitian ini & 40 \\
\hline & Jumlah data observasi $(40 \times 3)$ & 120 \\
\hline
\end{tabular}

Sumber: Data Penelitian, 2021

\section{HASIL DAN PEMBAHASAN}

Tabel 2, memperlihatkan hasil uji statistik deskriptif yang mana disajikan guna memberi bayangan dari sebuah data, yang dilihat berdasarkan total sampel, nilai mean, nilai minimum serta nilai maksimum, dan juga Standar Deviasi (Ghozali, 2016).

Tabel 2. Hasil Analisis Statistik Deskriptif

\begin{tabular}{lrrrrr}
\hline & $N$ & Minimum & Maximum & Mean & $\begin{array}{c}\text { Std. } \\
\text { Deviation }\end{array}$ \\
\hline Reputasi KAP & 120 & 0,00 & 1,00 & 0,408 & 0,493 \\
Prediksi Kebangkrutan & 120 & $-2,20$ & 1,98 & 0,508 & 0,718 \\
Profitabilitas & 120 & $-1,94$ & 0,86 & 0,094 & 0,272 \\
Audit Delay & 120 & 0,00 & 205,00 & 87,050 & 36,612 \\
Valid N (listwise) & 120 & & & & \\
\hline
\end{tabular}

Sumber: Data Penelitian, 2021

Tabel 2, menunjukkan bahwa jumlah pengamatan dalam penelitian ini sebanyak 120 data dilihat dari kolom N. Audit delay pada dalam Tabel 2, memiliki jumlah 120 data dengan nilai minimum adalah 0 dan nilai maksimum 205. Audit delay mempunyai nilai mean 87,05 dan standar deviasi yaitu 36,612. Reputasi KAP memiliki jumlah 120 data dengan nilai minimum adalah 0 dan nilai maksimum 1 . Reputasi KAP memiliki nilai mean 0,408 serta standar deviasi yaitu 0,493. Prediksi Kebangkrutan memiliki jumlah 120 data dengan nilai minimum yaitu -2,20 serta nilai maksimum 1,98. Prediksi Kebangkrutan memiliki nilai mean yaitu 0,508 serta standar deviasi yakni 0,718. Profitabilitas memiliki jumlah 120 data dengan nilai minimum yakni $-1,94$ serta nilai maksimum 0,86 . Profitabilitas memiliki nilai mean 0,094 serta standar deviasi yaitu 0,272. 
Analisis regresi linier berganda digunakan untuk mengetahui seberapa besar pengaruh variabel bebas dan terikat pada suatu penelitian. Penelitian ini menggunakan Analisis regresi linier yang diuji dengan taraf signifikansi 5 persen. Variabel yang diuji yaitu reputasi KAP, prediksi kebangkrutan, dan profitabilitas yang merupakan variabel bebas dan audit delay yang merupakan variabel terikat. Adapun hasil dari analisis regresi linear berganda penelitian ini disajikan pada Tabel 3.

Tabel 3. Hasil Analisis Regresi Linear Berganda

\begin{tabular}{|c|c|c|c|c|c|c|}
\hline \multirow{2}{*}{\multicolumn{2}{|c|}{ Model }} & \multicolumn{2}{|c|}{$\begin{array}{c}\text { Unstandardized } \\
\text { Coefficients }\end{array}$} & \multirow{2}{*}{  } & \multirow[b]{2}{*}{$\mathrm{t}$} & \multirow{2}{*}{ Sig. } \\
\hline & & B & $\begin{array}{l}\text { Std. } \\
\text { Error }\end{array}$ & & & \\
\hline \multirow[t]{4}{*}{1} & (Constant) & 103,654 & 3,764 & & 27,542 & 0,000 \\
\hline & Reputasi KAP & $-14,960$ & 6,102 & $-0,202$ & $-2,452$ & 0,016 \\
\hline & Prediksi Kebangkrutan & $-10,977$ & 4,737 & $-0,215$ & $-2,317$ & 0,022 \\
\hline & Profitabilitas & $-51,869$ & 11,595 & $-0,386$ & $-4,473$ & 0,000 \\
\hline
\end{tabular}

a. Variabel Dependen : Audit Delay

Sumber: Data Penelitian, 2021

Variabel reputasi KAP menghasilkan t-hitung yakni $-2,452$ serta nilai signifikansi $<0,05$, yaitu 0,016 (sig. $=0,016<0,05)$ memperlihatkan, reputasi KAP mempunyai pengaruh negatif dan signifikan pada audit delay. Ini berarti hipotesis pertama $\left(\mathrm{H}_{1}\right)$ yang berbunyi reputasi KAP mempunyai pengaruh negatif pada audit delay diterima. KAP yang berasosiasi dengan KAP big four mampu menyelesaikan audit lebih cepat daripada KAP non-big four. Hal ini karena reputasi KAP yang baik akan lebih tepat waktu dalam penyampaian laporan keuangan karena untuk menjaga image KAP. Disamping itu, KAP golongan big four diprediksikan mempunyai teknologi lebih mutakhir serta staf yang terspesialisasi alhasil dapat lebih efisien ketika menjalankan pekerjaan. (Verawati \& Wirakusuma, 2016). KAP yang bereputasi baik cenderung mempunyai staf khusus untuk mengurus kewajiban entitas publik dalam melakukan penyampaian laporan keuangan seperti yang diatur pada peraturan OJK, alhasil KAP big four cenderung lebih tepat waktu untuk melaporkan keuangannya daripada KAP non big four. Semakin baik reputasi sebuah KAP yang jasanya dipakai untuk melaksanakan audit laporan keuangan, semakin singkat pula rentang waktu yang dibutuhkan dalam penyampaian laporan keuangan auditan (Ahmed \& Cheahmad, 2016). KAP yang mempunyai afiliasi dengan big four mempunyai sumber daya manusia dengan kualitas cenderung lebih baik, mempunyai kompetensi, serta mempunyai banyak pengalaman kerja untuk melaksanakan kegiatan pengauditan. Hasil ini selaras dengan penelitian oleh Verawati \& Wirakusuma (2016) serta Ocak \& Ozden (2018).

Variabel prediksi kebangkrutan menghasilkan t-hitung yakni -2,317 serta nilai signifikansi yang lebih kecil dibandingkan 0,05, yaitu sebesar 0,022 (sig. = $0,022<0,05$ ) menunjukkan bahwa prediksi kebangkrutan mempunyai pengaruh negatif serta signifikan pada audit delay. Hal tersebut menjelaskan bahwa hipotesis kedua $\left(\mathrm{H}_{2}\right)$ yang berbunyi prediksi kebangkrutan mempunyai pengaruh negatif pada audit delay diterima. Entitas dengan skor rendah dalam perhitungan prediksi kebangkrutan, biasanya akan mengulur waktu penyampaian laporan keuangan 
ke publik. Sebabnya adalah perusahaan yang memiliki skor kecil cenderung bersifat akan bangkrut. Sesuai dengan teori kepatuhan, kesulitan finansial ini membuat auditor mengalami kesulitan dalam penentuan opini, khususnya penilaian mengenai going concern. Penilaian going concern ini akan memperlambat proses audit sehingga memperlambat publikasi laporan auditor independen. Auditor tidak hanya menilai kewajaran penyajian laporan keuangan, melainkan juga bertanggung jawab untuk mengevaluasi keberlangsungan hidup perusahaan. Prediksi kebangkrutan yang tinggi cenderung membuat auditor menetapkan risiko audit lebih tinggi, khususnya risiko deteksi audit. Penetapan risiko audit yang mendalam akan dilakukan auditor guna memastikan dan menilai keadaan perusahaan di masa depan. Proses mengurangi risiko deteksi tersebut, auditor akan mengatasinya dengan menambah jumlah sampel audit, sehingga ini akan berdampak pada penyelesaian proses audit yang memakan waktu lebih banyak. Hal ini akan membuat kemunduran dalam publikasi laporan auditor independen. Informasi kebangkrutan ini akan memperngaruhi laporan keuangan sehingga publik menganggap informasi ini sebagai bad news. Jika dipublikasikan ke publik maka dapat memperburuk citra perusahaan (Santosa \& Dwirandra, 2016). Keterlambatan publikasi laporan keuangan akan mengurangi nilai informasi dari laporan keuangan tersebut yang akan menimbulkan asimetris informasi (Normalita et al., 2018). Hasil penelitian ini sejalan dengan hasil penelitian dari (Santosa \& Dwirandra 2016).

Variabel profitabilitas menghasilkan t-hitung sebesar $-4,473$ dan nilai signifikansi lebih kecil dibandingkan 0,05, yaitu sebesar 0,000 (sig. $=0,000<0,05$ ) menunjukkan, profitabilitas mempunyai pengaruh negatif dan signifikan pada audit delay. Jadi hipotesis ketiga $\left(\mathrm{H}_{3}\right)$ yang berbunyi profitabilitas mempunyai pengaruh negatif pada audit delay diterima. Sebagian besar entitas saat memperoleh peningkatan laba akan lebih cepat dalam hal publikasi. Disamping itu, tekanan yang tinggi dari pihak yang mempunyai kepentingan akan mendorong entitas untuk lebih cepat dalam menyampaikan laporan keuangan yang telah diaudit. Apabila perusahaan yang memiliki profitabilitas rendah, menandakan perusahaan melemah dalam kinerjanya. Ini sejalan dengan teori kepatuhan bahwa auditor akan lebih sulit memberikan opini going concern, sehingga akan memperlambat proses audit. Auditor ditekankan untuk mematuhi aturan yang berlaku dengan cara mengikuti prosedur audit yang berlaku agar laporan keuangan yang diaudit sudah akurat dan bermanfaat untuk publik. Oleh karena itu, kinerja perusahaan yang menurun membuat auditor akan melakukan prosedur audit yang lebih mendalam, khususnya pada penentuan risiko audit. Pendalamaan dalam menentukan risiko tersebut akan memperlambat pelaksanaan uji audit, sehingga pelaksanaan prosedur audit yang lebih mendalam ini akan memengaruhi rentang waktu audit delay yang dapat menjadi lebih panjang. Hasil penelitian ini sesuai dengan teori sinyal dimana penyampaian laporan keuangan lebih cepat apabila perusahaan mengalami laba karena hal inimerupakan kabar baik yang mampu meningkatkan nilai sebuah entitas di mata para pemangku kepentingan, baik itu pemilik modal maupun kreditur. Sebaliknya apabila perusahaan yang memiliki profitabilitas rendah biasanya membujuk auditor melakukan penjadwalan audit agar lebih lama dari waktu yang seharusnya, jadi informasi dianggap "bad news" oleh masyarakat karena 
keterlambatan tersebut (Suparsada \& Putri, 2017). Penelitian ini juga sejalan sesuai dengan teori keagenan dimana dengan publikasi laporan keuangan secara tepat waktu yang dipengaruhi oleh profitabilitas akan mengurangi asimetris informasi terhadap para principal. Penelitian ini memperlihatkan hasil yang selaras dengan penelitian terdahulu oleh Suparsada \& Putri, (2017) dan Gunarsa \& Putri (2017) yang menyatakan bahwa profitabilitas berpengaruh negatif terhadap audit delay.

\section{SIMPULAN}

Sesuai hasil analisis serta pembahasan yang dipaparkan di atas, dapat dibuat simpulan bahwa reputasi KAP mempunyai pengaruh negatif dan signifikan pada audit delay, prediksi kebangkrutan mempunyai pengaruh negatif dan signifikan pada audit delay, dan profitabilitas mempunyai pengaruh negatif signifikan pada audit delay. Hal ini berarti, reputasi KAP, prediksi kebangkrutan dan profitabilitas pada suatu perusahaan akan mempengaruhi audit delay. Perusahaan sebaiknya lebih meningkatkan usaha dalam pencapaian profitabilitas dan juga memperhatikan kesehatan keuangan perusahaan agar dapat menerbitkan laporan auditor independen secara tepat waktu. Dengan publikasi secara tepat waktu juga membuat para investor lebih percaya menanamkan modalnya di perusahaan tersebut. Selain itu, bagi entitas public diharapkan mampu memberi kewenangan dan kepercayaam pada auditor untuk menjalankan hal yang seharusnya dikerjakan, sehingga auditor dapat dengan cepat menyelesaikan proses audit. Saran untuk peneliti berikutnya, yaitu melaksanakan penelitian yang sifatnya sama namun pada sektor lainnya, sehingga didapatkan sampel lebih banyak, alhasil mampu menguatkan simpulan penelitian-penelitian sebelumnya. Selain itu, masih adanya variabel lain di luar penelitian ini yang mempengaruhi audit delay sebuah entitas, untuk itu sebaiknya mempertimbangkan variabel lain sebagai variabel yang mampu mempengaruhi audit delay.

\section{REFERENSI}

Abdillah, M. R., Mardijuwono, A. W., \& Habiburrochman. (2019). The effect of company characteristics and auditor characteristics to audit report lag. Asian Journal of Accounting Research, 4(1), 129-144. https://doi.org/10.1108/AJAR05-2019-0042

Ahmed, M. I., \& Che-ahmad, A. (2016). Effects of Corporate Governance Characteristics on Audit Report Lags. International Journal of Economics and Financial Issues, 6(7), 159-164.

Akingunola, R. O., Soyemi, K. A., \& Okunuga, R. (2018). Client Attributes and the Audit Report Lag in Nigeria. 13(1), 30-41.

Aprila, N., Fachruzzaman, \& Pratiwi, D. S. (2017). Pengaruh Opini Audit dan Kualitas Auditor Terhadap Audit Delay pada Pemerintah Kabupaten/Kota Di Indonesia. Jurnal Akuntansi, 7(3), 75-86.

Arifuddin, Hanafi, K., \& Usman, A. (2017). Company Size , Profitability , and Auditor Opinion Influence to Audit Report Lag on Registered Manufacturing Company in Indonesia Stock Exchange. International Journal of Applied Business and Economic Research, 15(19), 353-367.

Aslam, S., Makki, M. A. M., \& Iqbal, S. M. J. (2017). Driving Force Behind Audit Report Lag: A Comparison between Auditor Independence and Knowledge 
Spillovers. A Research Journal of Commerce, Economics, and Social Sciences, 11(2), 151-157. https:// doi.org/10.24312/ paradigms110204

Ghozali, I. (2016). Aplikasi Analisis Multivariete Dengan Program IBM SPSS 23. Semarang: Badan Penerbit Universitas Diponegoro.

Gunarsa, I. G. A. C., \& Putri, A. D. (2017). Pengaruh Komite Audit, Independensikomite Audit, dan Profitabilitas Terhadap Audit Report Lag di Perusahaan Manufaktur. E-Jurnal Akuntansi Universitas Udayana, 20(2), 16721703.

Hapsari, A. N., Putri, N. K., \& Arofah, T. (2016). The Influence of Profitability, Solvency, And Auditor 'S Opinion To Audit Report Lag at Coal Mining Companies. Binus Business Review, 7(2), 197-201. https:// doi.org/10.21512/bbr.v7i2.1685

Harahap, S. S. (2008). Analisis Kritis Atas Laporan Keuangan. Jakarta: PT Raja Grafindo Persada.

Heryanto, A. C. N. (2020). Analisis Prediksi Kebangkrutan Perusahaan dengan Model Grover. Competitive Jurnal Akuntansi dan Keuangan. Jurnal Akuntansi Dan Keuangan, 4(2), 54-65.

Jayanti, Q., \& Rustiana. (2015). Analisis Tingkat Akurasi Model-Model Prediksi Kebangkrtuan untuk Memprediksi Voluntary Auditor Switching. MODUS Jurnal Ekonomi Dan Bisnis, 27(2), 87-108.

Kaaroud, M. A., Ariffin, N. M., \& Ahmad, M. (2020). The extent of audit report lag and governance mechanisms in Malaysia. Journal of Islamic Accounting and Business Research, 11(1), 70-89. https:/ / doi.org/10.1108/JIABR-05-2017-0069

Kasmir. (2014). Analisis Laporan Keuangan. Jakarta: Raja Grafindo Persada.

Lestari, C. S., Rasyidi, A., \& Susanti, W. (2017). Pengaruh Reputasi KAP, Opini Audit Dan Komite Audit Terhadap Audit Delay Pada Perusahaan Perbankan Yang Terdaftar Di Bursa Efek Indonesia Tahun 2013-2015. Jurnal Ekonomi Akuntansi, 3(3), 389-403.

Lestari, S. Y., \& Nuryatno, M. (2018). Factors Affecting the Audit delay and Its Impact on Abnormal return in Indonesia Stock Exchange. International Journal of Economics and Finance, 10(2), 48-56.

Normalita, V., Ts, K. H., Studi, P., Universitas, A., \& Batik, I. (2018). Faktor yang Mempengaruhi Audit Delay (Studi Empiris perusahaan manufaktur sektor industri dasar dan kimia yang Terdaftar di BEI). Jurnal Riset Ekonomi Manajemen, Bisnis Dan Akuntansi, 8(1), 538-544.

Ocak, M., \& Özden, E. A. (2018). Signing Auditor-Specific Characteristics And Audit Report Lag: A Research From Turkey. The Journal of Applied Business Research, 34(2), 277-294.

Panggabean, A. P., \& Yendrawati, R. (2016). The Effect of Corporate Governance, Tenure Audit And Quality of Earnings Towards Audit Delay With Auditor 'S Specialization as The Variable of Moderation. Asian Journal of Innovation and Entrepreneurship, 01(01), 48-61.

Prabasari, I. G. A. A. R., \& Merkusiwati, N. K. L. A. (2017). Pengaruh Profitabilitas, Ukuran Perusahaan, dan Komite Audit pada Audit Delay yang Dimoderasi oleh Reputasi Kap. E-Jurnal Akuntansi Universitas Udayana, 20(2), 1704-1733.

Praptika, P. Y. H., \& Rasmini, N. K. (2016). Pengaruh Audit Tenure, Pergantian Auditor dan Financial Distress pada Audit Delay pada Perusahaan 
Consumer Goods. E-Jurnal Akuntansi Universitas Udayana, 15(3), 2052-2081.

Pratiwi, C. I. E., \& Wiratmaja, I. D. N. (2018). Pengaruh Audit Tenure Dan Kompleksitas Operasi Terhadap Audit Delay Perusahaan Pertambangan Di BEI Tahun 2013-2016. E-Jurnal Akuntansi Universitas Udayana, 24(3), 19641989.

Riyanto, B. (2012). Dasar-dasar Pembelanjaan Perusahaan. Yogyakarta: BPFE.

Salleh, Z., Baatwah, S. R., \& Ahmad, N. (2017). Audit Committee Financial Expertise and Audit Report Lag: Malaysia Further Insight. Asian Journal of Accounting and Governance, 8, 137-150.

Santosa, W. I., \& Dwirandra, A. A. N. B. (2016). Kualitas Kantor Akuntan Publik Memoderasi Pengaruh Probabilitas Kebangkrutan Terhadap Audit Delay. EJurnal Akuntansi Universitas Udayana, 17(3), 1891-1923.

Saragih, M. R. (2019). The Effect of Company Size, Solvency and Audit. Sientific Journal of Reflection: Economic, Accounting, Managemend and Business, 2(2), 191200. https://doi.org/10.5281/zenodo.2628084

Sari, R. A. I., \& Priyadi, M. P. (2016). Pengaruh Leverage, Profitabilitas, Size, dan Growth Opportunity Terhadap Nilai Perusahaan. Jurnal Ilmu Dan Riset Manajemen, 5(10), 1-17.

Sari, W. O. I., Subroto, B., \& Ghofar, A. (2019). Corporate Governance Mechanism and Audit Report Lag Moderated by Audit Complexity. International Journal of Research in Business and Social Science, 8(6), 256-261.

Scott, W. (2012). Financial Accounting Theory International Fifth Edition. New Jersey: Prentice Hall Inc.

Soyemi, K. A., Sanyaolu, W. A., \& Salawu, R. O. (2019). Corporate Governance Practices and External Auditors Reporting Lag in Nigeria. International Accounting and Taxation Research Group, 3(4), 15-31.

Spence, M. (1973). Job Market Signaling. The Quarterly Journal of Economics, 8(73), 355-374.

Sugiyono. (2017). Metode Penelitian Kuantitatif, Kualitatif, dan RED. Bandung: Alfabeta

Suparsada, N. P. Y. D., \& Putri, A. D. (2017). Pengaruh Profitabilitas, Reputasi Auditor, Ukuran Perusahaan, dan Kepemilikan Institusional Terhadap Audit Delay pada Perusahaan Manufaktur. E-Jurnal Akuntansi Universitas Udayana, 18(1), 60-87.

Tyler, T. R. (1989). The Psychology of Procedural Justice. Journal of Personality and Social Psychology. Journal of Personality and Social Psychology, 57(5), 830838.

Verawati, N. M. A., \& Wirakusuma, M. G. (2016). Pengaruh Pergantian Auditor, Reputasi Kap, Opini Audit dan Komite Audit pada Audit Delay. E-Jurnal Akuntansi Universitas Udayana Vol.17.2., 17(2), 1083-1111.

Warrad, L. H. (2018). The Extent to Which the Corporate Governance Characteristics Has Affected the Audit Report Lag in Jordanian Banks. International Journal of Business and Management, 13(12), 81-92. https:// doi.org/10.5539/ijbm.v13n12p81

Yohaniar, E., \& Asyik, N. F. (2017). Pengaruh Profitabilitas , Solvabilitas , Size , Komite Audit, Kompleksitas Operasi dan Opini Auditor Terhadap Audit Delay. Jurnal Ilmu Dan Riset Akuntansi, 6(12), 1-19. 